\title{
Wisconsin Labor History Society Conference
}

\section{Shelton Stromquist}

University of lowa

Historic Turner's Hall in Milwaukee was the site for the first annual conference of the Wisconsin Labor History Society, held appropriately on May 1, 1982. The hall has been the scene of numerous gatherings of working men and women for nearly one hundred years. This meeting, the first of the newly formed labor history society, upheld the tradition well. One hundred and fifty people--trade union activists, labor historians, and rank and file union members-spent a full day exploring Milwaukee's labor history and charting the future course of the state labor history society.

The program began with a session on "Unity and Conflict: Milwaukee Labor in the 1940s." Two labor historians, Rick Pifer from the University of WisconsinEau Claire and Steve Meyer from the Illinois Institute of Technology, discussed their current research. Pifer presented an overview of the effects of World War II on Milwaukee labor, stressing the contributions made to war production in the face of social dislocation and inflation. The later war years saw rising levels of conflict as labor and management positioned themselves for a return to peacetime labor relations. Workers were particularly concerned that earnings based on overtime and promotion in a tight labor market would not be maintained. Conflicts also centered on the maintenance of basic union rights won during the war.

Steve Meyer analyzed the emergence of a "workplace rule of law" exercised by shopfloor activists of UAW Local 248 at Allis Chalmers during the war. He argued that it was this challenge to management prerogatives and authority that provides the context for understanding the titanic eleven-month strike of 1946-47, not the left-wing politics of the union's leadership. The UAW local was initially formed as a loose federation of several metal and electrical unions during the mid-1930s. Allis Chalmers reluctantly granted recognition after two bitter strikes in 1939 and 1941. Agreement was reached to use an impartial referee as the final step in the grievance procedure. Effectively organized through a network of shop stewards, the union identified grievances, selected critical issues, and in carefully structured interpretations of the contract consistently won rulings before the referee that broadened scope of the contract in such areas as seniority, supervision, working conditions and production methods. The effect was to chip away at the Taylorist premises of management's control of the workplace. At the war's end, Allis Chalmers unilater- 
ally dismissed the referee, obstructed the grievance procedure and set the stage for a bitter strike that ended with the dismissal of over ninety officers, committeemen and shop stewards from UAW Local 248 and broke the back of militant unionism at the plant. The company managed to make the alleged communist orientation of the union's leadership, the issue.

The two very interesting presentations were followed by brief comments from four Milwaukee trade union activists. Gordon King, a former officer of the Plumbers Union, suggested ways in which the wartime experiences of building trades workers paralleled those of industrial workers. Florence Simons stressed the important role of women in the labor force and the organizational drives of the late thirties and war years. Ralph Koenig, a regional director of the UAW, disagreed with Meyer's interpretation of the Allis-Chalmers strike. He argued that the leadership had unnecessarily injected their politics into the union and their management of the strike. This made them vulnerable to attacks by the company.

Following the luncheon, John Schmitt, president of the Wisconsin State AFL-CIO, spoke about the founding of the State Federation and read portions of the original statement of principles. He suggested that with minor adjustments it would serve today as well as it had in 1893 .

The afternoon program was centered around a labor history bus tour of Milwaukee organized and led by former socialist Mayor Frank Zeidler. Conference participants boarded three buses and visited the site of the famous Bay View Massacre in 1886, the old German and Polish working class neighborhoods, the site of the Milwaukee Leader offices, the haymarket, the public housing built during Milwaukee's socialist administrations and the new headquarters of the Wisconsin State AFL-CIO. At the state federation offices, a historic marker was dedicated commemorating the founding of the federation in 1893. The program concluded with brief remarks by John Schmitt and a few rousing labor songs.

The Wisconsin Labor History Society is developing a broad educational program. The society wants to see more attention to labor history in the schools, the collection and preservation of records that document workers' lives and struggles, and publications and speakers that can deepen the interest of the labor movement in its own history. It publishes a quarterly newsletter and sponsors an annual spring conference. The president of the organization is Joanne Ricca of Milwaukee. Dues are $\$ 5.00$ for an individual; $\$ 2.50$ for retirees and unemployed persons; and $\$ 25.00$ for organizations. For more information write: Wisconsin Labor History Society, P.O. Box 3471, Madison, Wisconsin 53704. 